\title{
Emergency Communications Deficiency Locator
}

Austin Collins

University of South Florida

Advisors:

Arcadii Grinshpan, Mathematics and Statistics Arsalan Akram Malik, Mathematics and Statistics

Sean Collins, Fort Knox Fire and Communications

Problem Suggested By: Austin Collins

Follow this and additional works at: https://digitalcommons.usf.edu/ujmm

Part of the Mathematics Commons, and the Other Applied Mathematics Commons

UJMM is an open access journal, free to authors and readers, and relies on your support: Donate Now

\section{Recommended Citation}

Collins, Austin (2021) "Emergency Communications Deficiency Locator," Undergraduate Journal of Mathematical Modeling: One + Two: Vol. 11: Iss. 2, Article 5.

DOI: https://doi.org/10.5038/2326-3652.11.2.4933

Available at: https://digitalcommons.usf.edu/ujmm/vol11/iss $2 / 5$ 


\title{
Emergency Communications Deficiency Locator
}

\begin{abstract}
The Bi-Directional Amplifier (BDA) is the newest edition to Life Safety in the state of Florida. The Florida Fire Prevention Code (NFPA 1) section 11.10.1 states that "In all new and existing buildings, minimum radio signal strength for fire department communications shall be maintained at a level determined by the authority having jurisdiction (Committee NFPA 1: Fire Code 2018). That authority having jurisdiction for our local Tampa Bay area is the Hillsborough County Fire Rescue department and they have posted their own requirements along with the Florida Senate for emergency communication standards. All existing "Hi-rise" buildings, 75 feet tall or more, must comply by Jan. $1^{\text {st }} 2022$, all existing apartment complexes must comply by 2025 , and all existing buildings that do not comply with the Hillsborough County Fire Rescue department standards were supposed to have applied for permit by December of 2019 (Senate Florida Legislature). Several building owners are unaware of the aforementioned changes and it is extremely important to efficiently identify the buildings that do not comply with the latest regulations.

To begin determining the best fix for soft spots in public safety radio transmissions I considered three separate FCC callsigns that cover the emergency radio channels around Hillsborough County. Next, I recorded the amount of Watts each tower is using to then convert to decibel gain $(\mathrm{dB})$ that each tower produces. I determined that greater the power (Watts) that you push through a tower has a decreasing rate of decibels produced per watt and therefore not an option to solve the problem at hand. Then I derived an expression for "Free Space Path Loss (FSPL) in dB" that shows the dissipation of radio signal over a given distance. Using this formula, I realized I may not be able to provide an overall solution for the lack of radio signal, but I would be able to locate areas that will require the installation of a radio amplification system. Therefore, using derivative and integration techniques, I have designed a precise method for mapping areas of radio propagation around Hillsborough County, which in turn, show areas that do not receive the minimal $-95 \mathrm{~dB}$ radio strength and must have a BDA installed.
\end{abstract}

\section{Keywords}

fire prevention control, fire rescue department standards, radio wave propagation, bi-directional amplification system(BDA)

\section{Creative Commons License} (c) (i) (2)

This work is licensed under a Creative Commons Attribution-Noncommercial-Share Alike 3.0 United States License. 


\section{PROBLEM STATEMENT}

Bi-directional Amplification systems are now mandated in the state of Florida, per the Florida Fire Prevention Code, and Fort Knox Fire and Communications needs a solution to provide public safety radio coverage at a more efficient rate.

\section{$\underline{\text { MOTIVATION }}$}

The evolving Life Safety code is one of the most important progressions in society today. Fire alarm systems, suppression systems, radio communication systems, etc. play a critical role in ensuring public safety under extreme circumstances. These new "two-way radio communications" systems allow firefighters, police, and EMT's to have immediate access to communication to one another during an emergency within a building. And that is why the BiDirectional Amplification systems, BDA, were introduced in the last updated Florida Fire Prevention Code. From an engineering aspect, when a new project is being drawn up, engineers must list out a set of specifications required to be implemented in the building design by hired contractors. Now the new radio communications code can be tricky to decipher when it comes to new construction. In an existing building, the building owner can hire a company to take radio strength readings to determine if the building has sufficient emergency communication signal. But for new construction, there is no building to do these readings in! And sure, you may take readings from the ground level where construction will take place, but that leaves out too many uncalculated variables like radio wave diffraction, decibel dissipation, and the effect of decibel gain from initial transmission. On the other side of that coin, the general contractor will not want to make the site owner pay for unnecessary building additions, like a BDA system, if they will fall within the acceptable decibel levels for clear two way radio communication. So, how do we predetermine radio strength for a given location without ever stepping foot on site? Through deriving a formula that gets down to the core understanding of radio wave propagation, accounting for as many variables as possible, and pinpointing where the edge of the curve that lies between areas within code and which are not.

\section{MATHEMATICAL DESCRIPTION \& SOLUTION APPROACH}

Since it was important to investigate how exactly FCC Callsigns transmit public safety frequencies, through RadioReference.com, I retrieved data from three specific tower sites that transmit into the same general area. Figure 1 shows a map of FCC callsign (Uniquely designated 
government agency frequencies) locations that cover the same intermediate area within the Hillsborough County limits. I will be using these same tower locations throughout the project.

Figure 1

(Hillsborough County (EDACS) - Site Map)

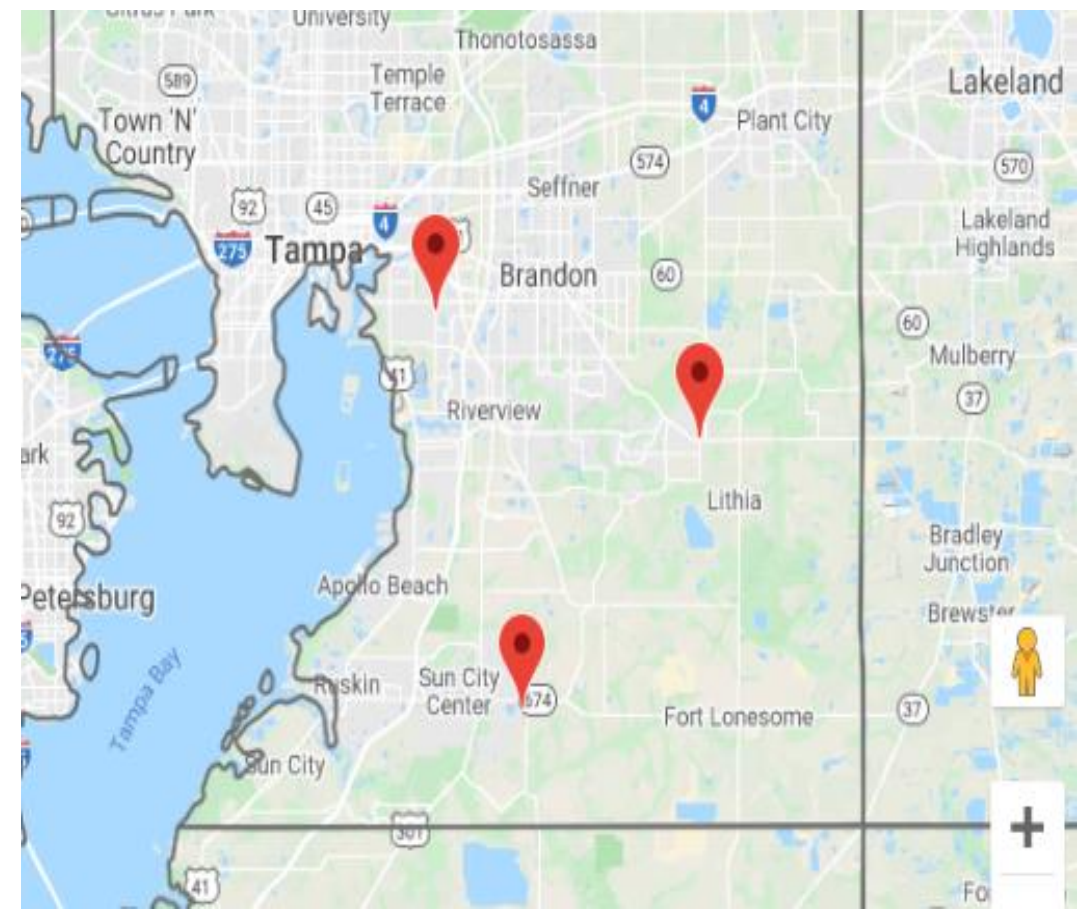

Figure 2 states the FCC Callsign addresses along with miscellaneous tower information.

Figure 2

(FCC Callsign WPDV262 (Hillsborough Co. Sheriff's Office))

\begin{tabular}{|l|l|l|l|l|l|l|}
\hline$\#$ & Tower ID & Type & Ant Height & Struc Height & Elevation & Address \\
\hline 1 & 1054317 & TOWER & 121.9 & 126.5 & 6.0 & 3212 S 78TH STREET \\
\hline 2 & & TOWER & 54.9 & 58.8 & 26.0 & 1120 7TH STREET \\
\hline 3 & & TOWER & 54.9 & 57.3 & 32.0 & 6766 LITHIA PINECREST ROAD \\
\hline
\end{tabular}

These three FCC Callsign locations operate under the Hillsborough County Sheriff's Office FCC license "WPDV262". All locations use an analog system voice and can be transmitted and received by Fire, EMT, and Police officers. Figure 3 shows the frequencies in which these officers communicate over for emergencies.

$\underline{\text { Figure } 3}$

Site Frequencies

(Hillsborough County (EDACS))

\begin{tabular}{|l|l|l|l|l|l|l|l|l|l|}
\hline 851.125 & 851.375 & 851.5625 & 851.700 & 851.825 & 852.3125 & 852.550 & 852.650 & 852.800 & 852.9125 \\
\hline 853.250 & 853.275 & 853.575 & 853.600 & 853.825 & & & & & \\
\hline
\end{tabular}


*for my project I will be using frequency $851.125 \mathrm{mHz}$

\section{$\underline{\text { Power in Watts to Decibels conversion }}$}

1. Through the following link you will see that each tower in Hillsborough County operates at an output power of 100 watts.

(ULS License $F C C$ )

2. The watts to decibel conversion formula: $g(x)=10 \cdot \log _{10}(1000 \cdot x)$

3. Input " $x$ " will be in watts and " $g(x)$ " will be in decibels or $\mathrm{dB}$ 's.

4. The goal of this calculation and the following graph (Figure 4 ) is to see the number of decibels that 100 watts puts off as well as how subtracting or adding more power will affect the number of decibels produced.

Figure $4 \quad g(x)=10 \cdot \log _{10}(1000 \cdot x)$

\section{Watts to Decibel Conversion}

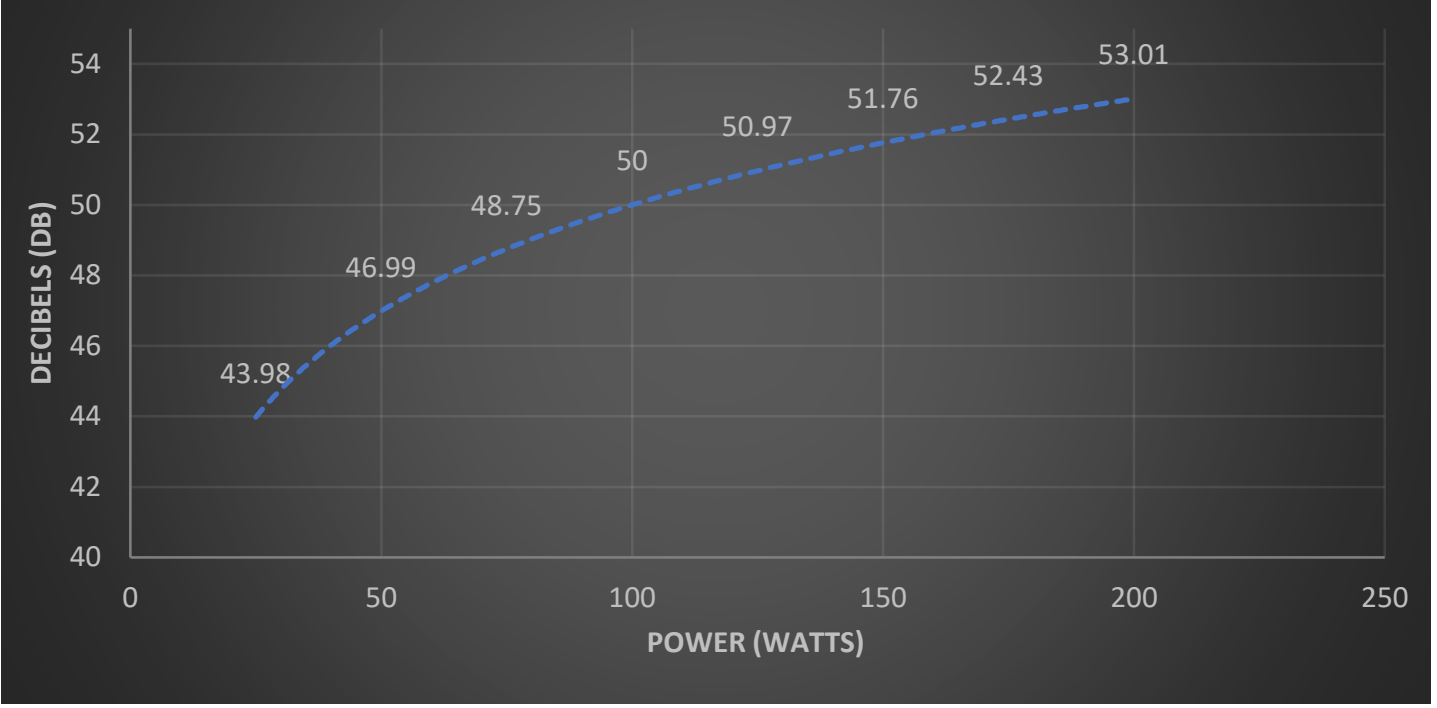

To further investigate the watts to decibel conversion I decided to take the derivative of the formula $g(x)=10 \cdot \log _{10}(1000 \cdot x)$ which gave me $g^{\prime}(x)=10 /(x \ln 10)$. Based on the derivative of the watts to decibel conversion formula we can determine if adding wattage to the tower transmitter locations is a viable solution for public safety radio coverage in the intermediate areas.

\section{Derivative of Power in Watts to Decibel conversion}

1. Derivation formula: $g^{\prime}(x)=\frac{10}{x \ln 10}$ Input " $x$ " will be in watts and " $g$ ' $(x)$ " will be in $\mathrm{dB} /$ watt. 
2. The goal of this calculation and the following graph (Figure 5) is to determine if $g(x)$ is increasing or decreasing as you apply more wattage to the transmitter tower.

Figure $5 \quad g^{\prime}(x)=10 /(x \ln 10)$

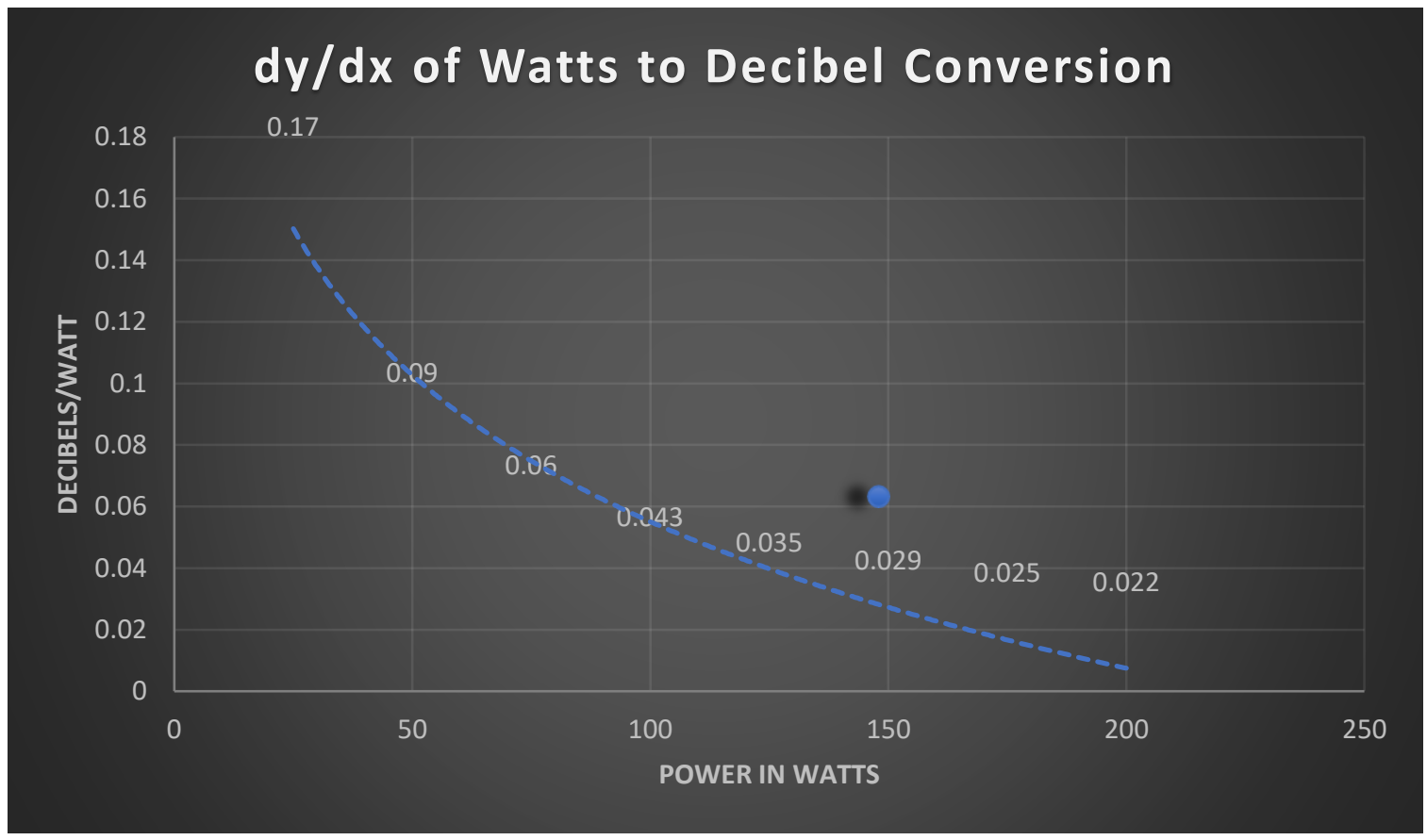

The $g^{\prime}(x)=\frac{10}{x \ln 10}$ graph has produced $y$-values that are above the $x$-axis and this tells us that $g(x)=10 \cdot \log _{10}(1000 \cdot x)$ is still increasing as you add more power to the tower. But, is this enough evidence to prove that adding more power will be a viable solution to public safety radio transmission? Let us take the second derivative to determine the overall trend of $g(x)$.

The second derivative of Power in Watts to Decibel conversion

1. Second Derivation Formula: $g^{\prime \prime}(x)=-\frac{10}{x^{2} \ln 10}$

2. The input " $x$ " will be in watts and $g$ " $(x)$ will be $\mathrm{dB}$ ' $\mathrm{s} /(\text { watt })^{2}$.

3. The goal of this calculation and the following graph (Figure 6) is to test the concavity of $g(x)$ in order to determine if increasing power produces an increased or decreased rate of dB's/watt. 
$\underline{\text { Figure } 6}$

$$
g^{\prime \prime}(x)=-\frac{10}{x^{2} \ln 10}
$$

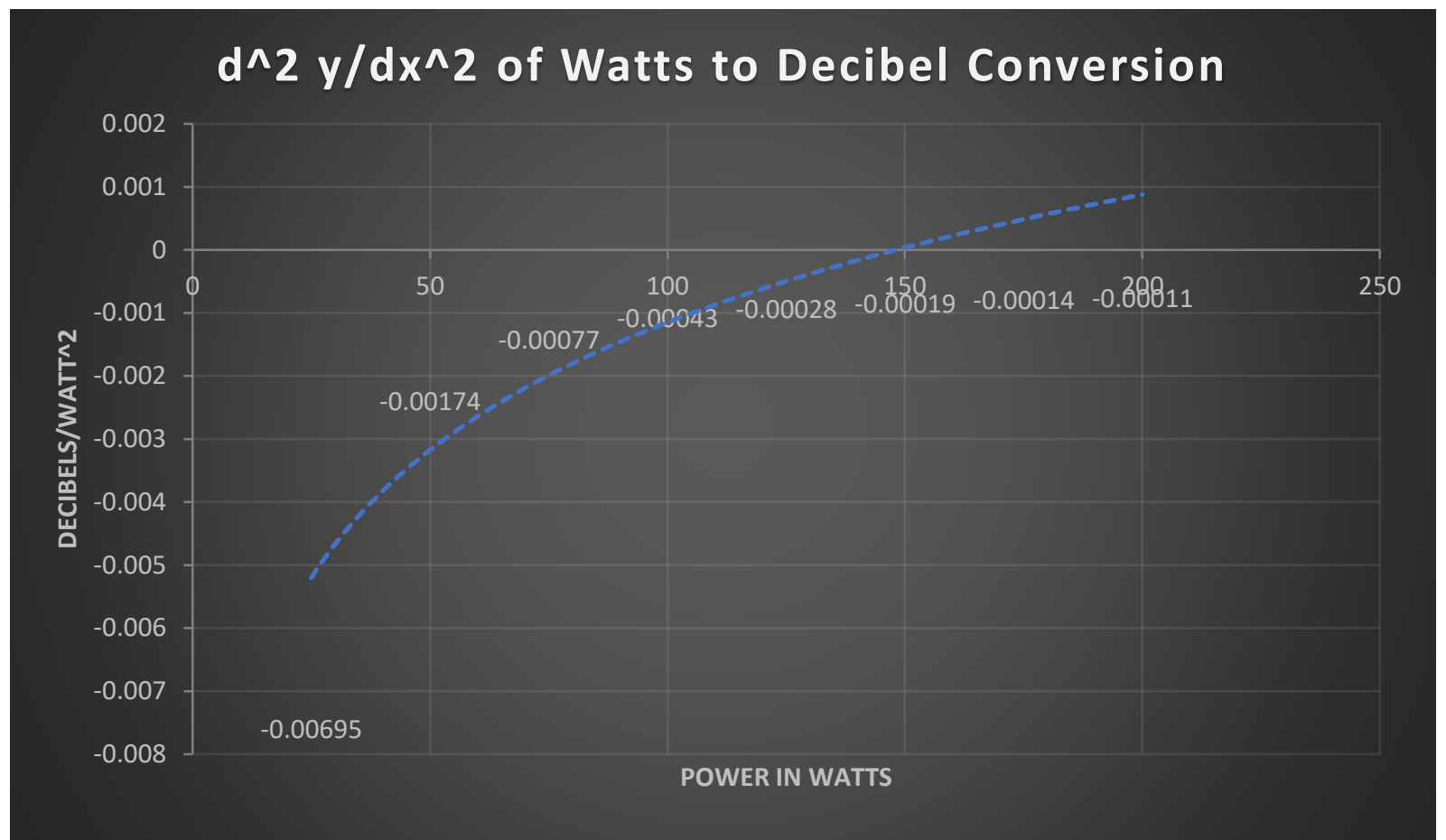

*Ignore the trend line eclipsing the $x$-axis, the $y$-values become infinitesimally small with the $\lim _{x \rightarrow \infty} g^{\prime \prime}(x)=0$.

The $g^{\prime \prime}(x)$ graph has produced all values below the $x$-axis which tells us that $g(x)=10 \cdot \log _{10}(1000 \cdot x)$ is concave downward. Ultimately, these derivations of our initial power to decibel conversion formula prove that as you add more power you get less decibel gain per watt added. Therefore, increasing transmitter tower power provides insignificant decibel gain and is not a viable solution for public safety radio coverage.

Now I will focus to devising an efficient process for locating "soft spots" in public safety radio coverage within my selected FCC callsigns intermediate area. This will allow my company to either locate existing buildings that will need a BDA system to be brought up to code, or to inform engineers on whether or not their new construction projects will need a BDA system transcribed into their specifications. Free Space Path Loss, or "FSPL", is a term used to define the dissipation of radio wave propagation over a given distance in space. I will first show how FSPL is derived, then, using a constant of 851.125 megahertz $(\mathrm{mHz})$ and an input of distance in kilometers $(\mathrm{km})$ as a variable, I will determine various decibel loss over a given distance.

\section{Deriving the Free Space Path Loss formula for dB's}

- Radio wave propagation path loss model:
(Chemguide.co.uk Wavelength and frequency) speed of light 


$$
\begin{aligned}
& L(x)=\left(\frac{4 \pi x}{\lambda}\right)^{2} \\
& { }^{*} \text { where } \lambda=c / v \\
& L(x)=\left(\frac{4 \pi x v}{c}\right)^{2}
\end{aligned}
$$

*where " $c$ " is the constant of the speed of light; " $v$ " stands for frequency

$$
L(x)=\left(4 \pi x v \cdot \frac{1 \cdot 10^{6}}{3 \cdot 10^{5}}\right)^{2}
$$

*for distance $(x)$ in kilometers; for $(v)$ in megahertz

- Now to get the $\mathrm{dB}$ version of the path loss model we must take the log of both sides of the equation multiplied by -10 :

$$
f(x)=-10 \log \left(4 \pi x v \cdot \frac{1 \cdot 10^{6}}{3 \cdot 10^{5}}\right)^{2}
$$

- Finally, we get the final equation for the $\mathrm{dB}$ version of the radio wave propagation path loss model as follows:

$$
f(x)=-\left(32.44+20 \log _{10}(v)+20 \log _{10}(x)\right)
$$

(Kuo, Derivation the $d B$ version of the Path Loss Equation for Free Space)

\section{The FSPL Formula for dB's}

1. FSPL formula: $f(x)=-\left(32.44+20 \log _{10}(v)+20 \log _{10}(x)\right)$

2. The input " $x$ " will be distance in kilometers and " $f(x)$ " will be in decibels. " $v$ " will be a constant of 851.125 megahertz.

3. The goal of this calculation and the following graph (Figure 7) is to determine free space path loss in decibels at various distances from the transmitter tower. 


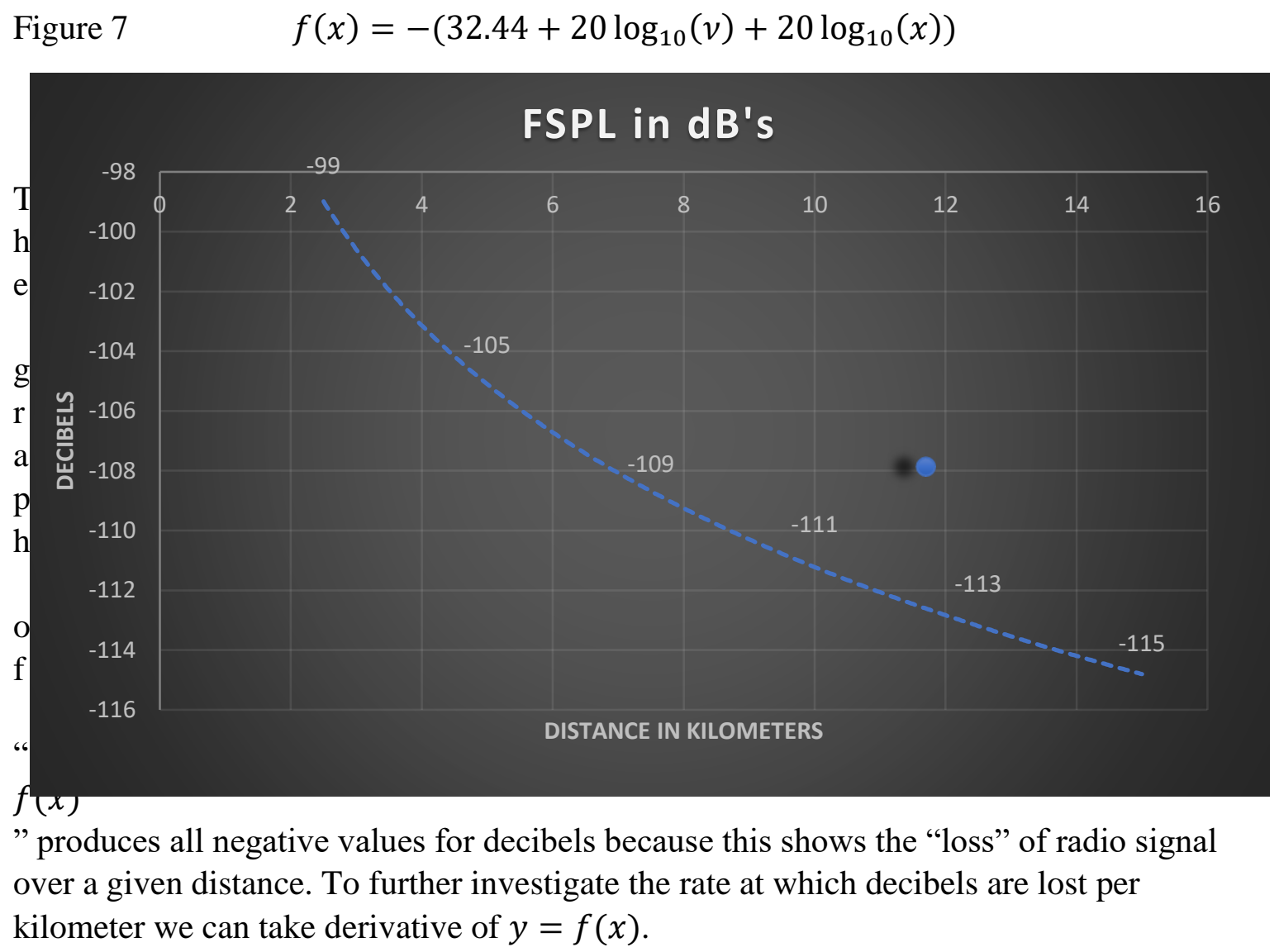

\section{$\underline{d y / d x \text { of the FSPL Formula }}$}

1. Derivation Formula: $f^{\prime}(x)=-\frac{20}{x \ln 10}$

2. The input " $x$ " will be distance in kilometers and " $f^{\prime}(x)$ " will be in $\mathrm{dB}$ ' $\mathrm{s} / \mathrm{km}$. Notice that your constant " $v$ " is not longer apart of the formula. This tells us the impact of frequency is insignificant to the overall decibel loss per kilometer.

3. The goal of this calculation and graph (Figure 8) is to determine decibel loss per kilometer as you travel further away from the transmitter tower and whether or not " $f(x)$ " is increasing or decreasing in lost decibels. 
Figure 8

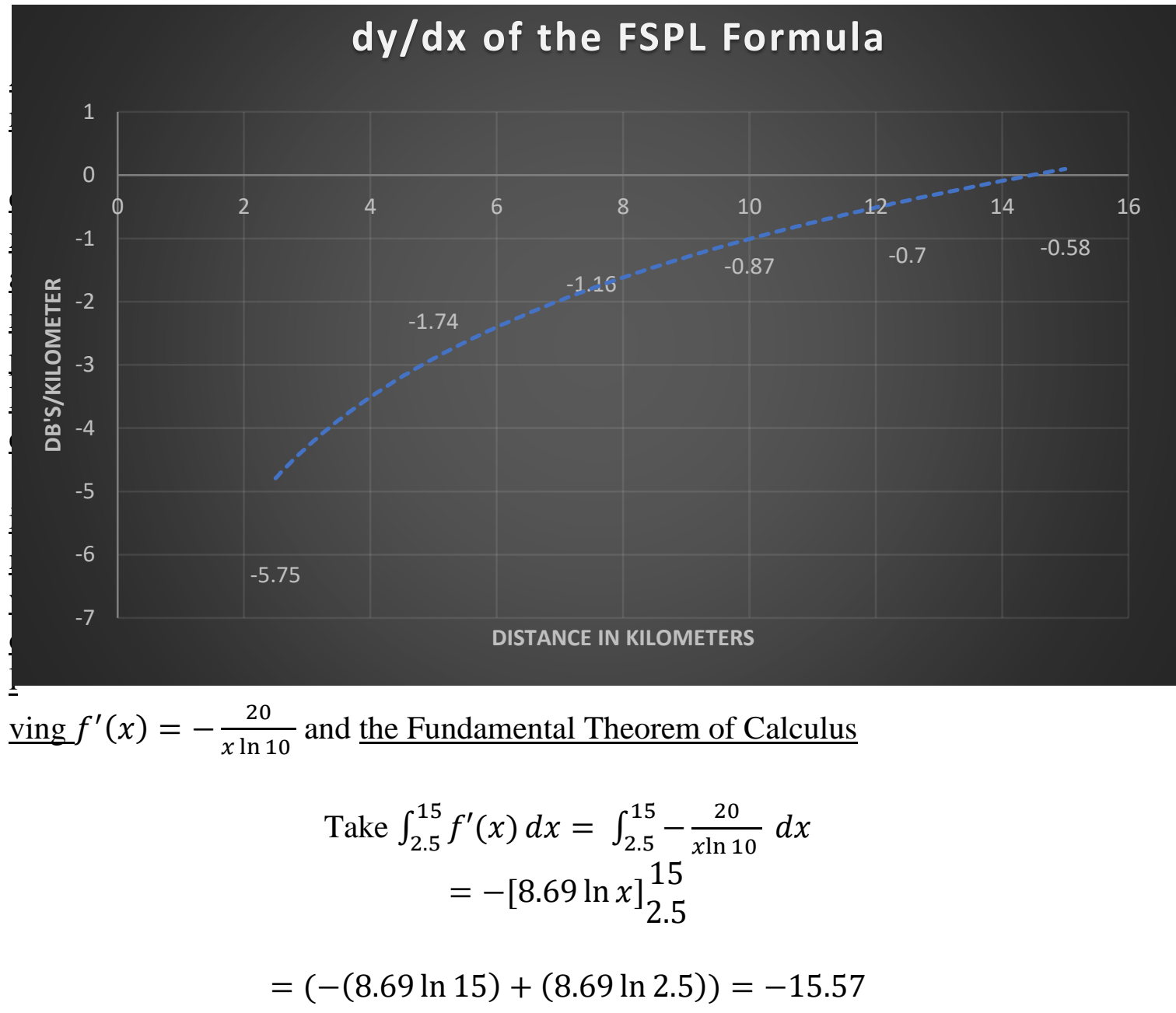

Now, if you take $f(15)-f(2.5)$ you get the same answer of -15.57 .

As you can see from $f^{\prime}(x)$, as you travel further from the transmitter tower you are still losing decibels per kilometer and therefore this graph shows that $f(x)$ is still increasing in decibel loss. If you take $f^{\prime \prime}(x)$ you would find that $f(x)$ has an upward concavity because of the negative sign, but if we ignore this negative sign the graph is actually concave down. Which means the rate at which your losing decibels/kilometer is slowing down the further you travel from the transmitter tower. Now this may seem confusing for someone who does not understand radio signal and the Free Space Path Loss formula. The reason you lose decibels at a slower rate the further you travel from a transmitter tower, is that as you approach $-120 \mathrm{~dB}$ 's communication becomes non-existent and this takes longer distance to develop. Remember, the standard that the Florida Fire prevention Code has set for acceptable $\mathrm{dB}$ loss for downlink (receive) and uplink (transmit) readings is $-95 \mathrm{~dB}$ 's. Understanding the difference between a downlink value 
and an uplink value is very important to this project and the public safety radio standards. Figure 9 will help put this into perspective.

Figure 9

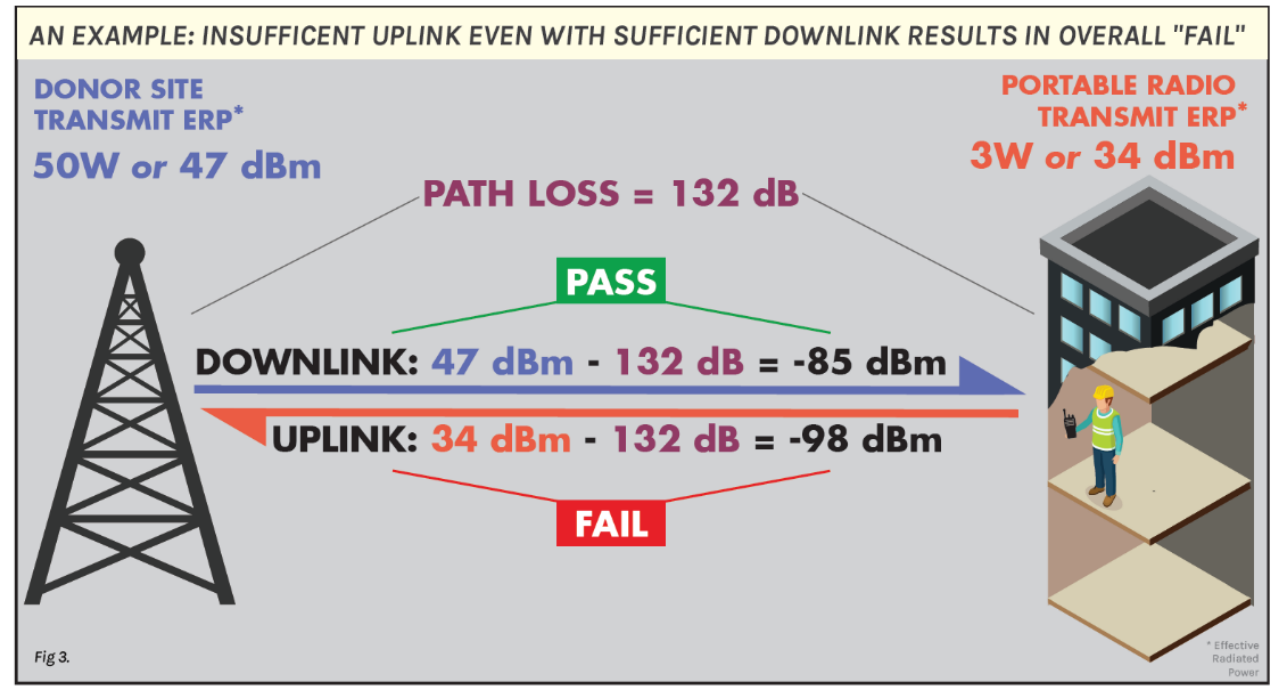

(B. Technical \& Sales Resources for RSI Distributors)

A downlink is a value of $\mathrm{dBm}$, or "decibel milliwatts", coming from the transmitter tower to the location in which you may be taking radio strength readings at to determine if the site is within code. Typically, this $\mathrm{dBm}$ value is being powered by 50-200 watts depending on the transmitter tower. Keep in mind, Figure 9 is using a 50-watt transmitter tower versus we are using 100-watt towers. Now, the uplink value is produced by a public safety portable radio that is only powered on average by 3-watts. Which has much less $\mathrm{dBm}$ output than the 100 watt towers we are using for this project. Therefore, for the uplink value $\geq(-95 \mathrm{~dB}$ 's) you must have a downlink value $\geq(-79 \mathrm{~dB}$ 's).

Difference in downlink vs. uplink value $=(50 \mathrm{~dB}$ 's $-34 \mathrm{~dB}$ 's $)=16 \mathrm{~dB}$ 's

\section{$\underline{\text { Building Material Decibel Loss Constants }}$}

So far, we have calculated the number of decibels a 100-watt tower produces and various free space path loss decibel values for a range of distance. The last variable I would like to account for before putting together the final formula is how different types of building material affect decibel loss. I have chosen to use three most common types of building material to create my "Emergency Communication Deficiency Locator" maps.

- Concrete Building Constant: $(C) \approx-25 d B^{\prime} s$

- Brick Building Constant: $(B) \approx-20 d B^{\prime} s$

- Wood Building Constant: $(W) \approx-15 d B^{\prime} s$ 
*All constants have been determined based on emergency communication site surveys carried out by myself for Fort Knox Fire and Communications, examples can be found in the Appendices. Readings taken outside the walls of the site versus readings taken on the insides of those walls gave me an approximation for these constants.

\section{Emergency Communications Deficiency Locator Formulas}

\section{Base Formula}

$$
(\text { Tower dB Gain })+(\text { FSPL }+ \text { Building Material Constant }) \geq-79 d B^{\prime} S
$$

\section{Extended Formulas}

$$
\begin{aligned}
& \left(\left(10 \cdot \log _{10}(1000(100))\right)+\left(-\left(32.44+20 \log _{10}(851.125)+20 \log _{10}(\text { distance })\right)-(C)\right) \geq-79 d B^{\prime} s\right. \\
& \left(\left(10 \cdot \log _{10}(1000(100))\right)+\left(-\left(32.44+20 \log _{10}(851.125)+20 \log _{10}(\text { distance })\right)-(B)\right) \geq-79 d B^{\prime} s\right. \\
& \left(\left(10 \cdot \log _{10}(1000(100))\right)+\left(-\left(32.44+20 \log _{10}(851.125)+20 \log _{10}(\text { distance })\right)-(W)\right) \geq-79 d B^{\prime} s\right.
\end{aligned}
$$

Acceptable Distances per Building Material Types and their Coverages

*Area of a circle: $\pi r^{2}$

1. Building type: Concrete Buildings

a. Acceptable Distances per dB readings $\geq-79 \mathrm{~dB}$ 's: $5.0 \mathrm{~km}$

$$
\text { i. } \quad \pi(5.0 \mathrm{~km})^{2}=78.5 \mathrm{~km}^{2}
$$

2. Building type: Brick Buildings

a. Acceptable Distances per $\mathrm{dB}$ readings $\geq-79 \mathrm{~dB}$ 's: $7.5 \mathrm{~km}$

$$
\text { i. } \quad \pi(7.5 \mathrm{~km})^{2}=176.7 \mathrm{~km}^{2}
$$

3. Building type: Wood Buildings

a. Acceptable Distances per dB readings $\geq-79 \mathrm{~dB}$ 's: $15 \mathrm{~km}$

$$
\text { i. } \quad \pi(15 \mathrm{~km})^{2}=706.9 \mathrm{~km}^{2}
$$

*All calculations can be found in the Appendices.

\section{DISCUSSION}

My work has produced coverage maps in which represent three local FCC Callsigns in the Hillsborough County area and their intermediate areas. My project name, "Emergency Communication Deficiency Locator", is represented by the space in between each propagation coverage shown in these maps. Propagation of radio waves spreads from a central location into the area of a circle, hence the reason I used the area of a circle formula to gather my coverages in the previous section. 


\section{Emergency Communication Deficiency Locator Maps}

1. Concrete Buildings: https://www.mapdevelopers.com/draw-circletool.php?circles $=\% 5 \mathrm{~B} \% 5 \mathrm{~B} 5000 \% 2 \mathrm{C} 27.918688 \% 2 \mathrm{C}$ -

82.368623\%2C\%22\%23AAAAAA $\% 22 \% 2 \mathrm{C} \% 22 \% 23000000 \% 22 \% 2 \mathrm{C} 0.4 \% 5 \mathrm{D} \% 2 \mathrm{C} \% 5 \mathrm{~B}$ 5000\%2C $27.850123 \% 2 \mathrm{C}-$

82.173469\%2C\%22\%23AAAAAA\%22\%2C\%22\%23000000\%22\%2C0.4\%5D\%2C\%5B 5000\%2C27.7080057\%2C-

$82.3041788 \% 2 \mathrm{C} \% 22 \% 23 \mathrm{AAAAAA} \% 22 \% 2 \mathrm{C} \% 22 \% 23000000 \% 22 \% 2 \mathrm{C} 0.4 \% 5 \mathrm{D} \% 5 \mathrm{D}$

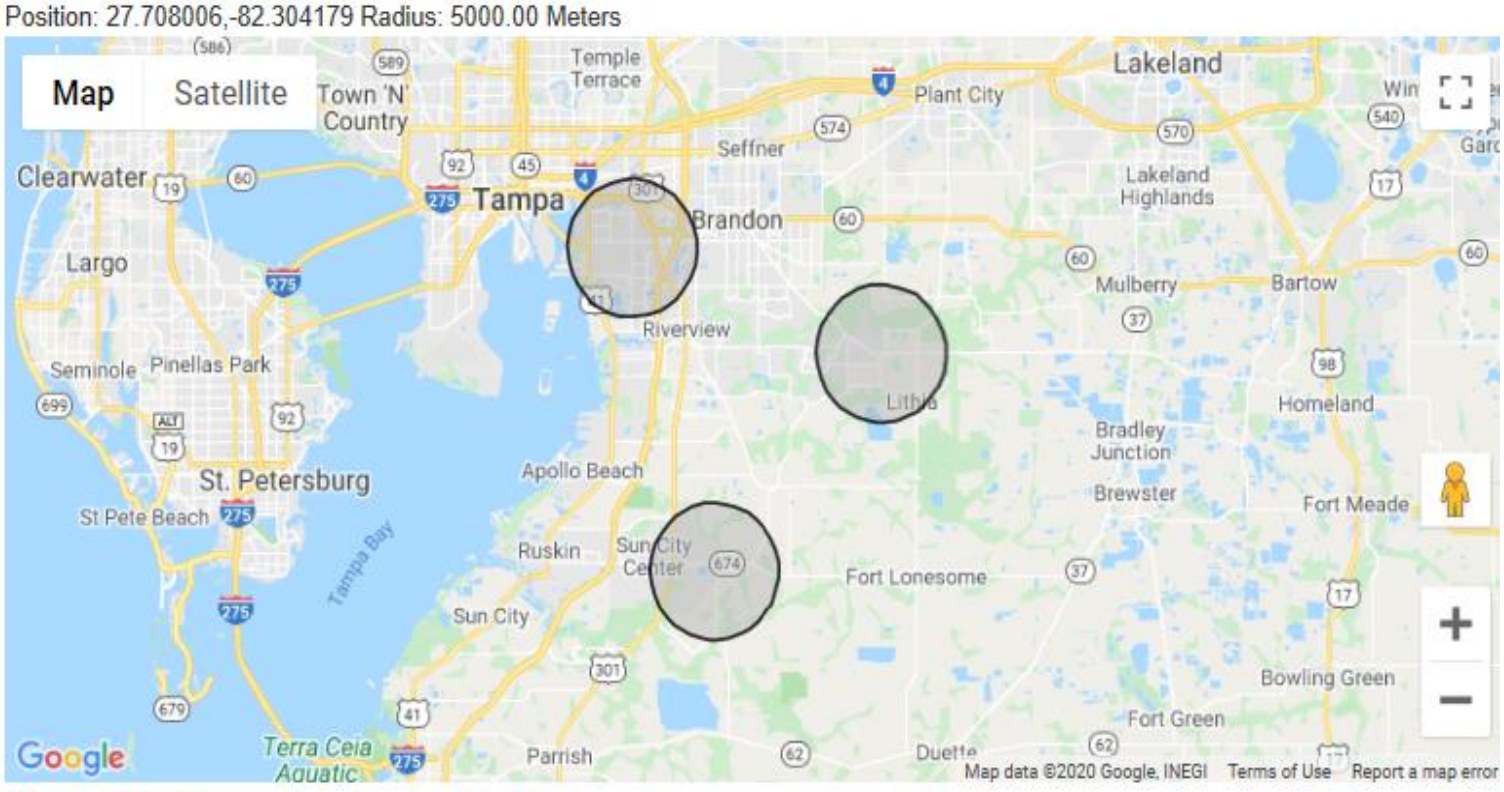

(Collins Map Developers Concrete buildings) 
Undergraduate Journal of M athematical M odeling: One +Two, Vol. 11, Iss. 2 [2021], Art. 5

2. Brick Buildings: https://www.mapdevelopers.com/draw-circletool.php?circles $=\% 5 \mathrm{~B} \% 5 \mathrm{~B} 7500 \% 2 \mathrm{C} 27.7080057 \% 2 \mathrm{C}$ -

$\underline{82.3041788 \% 2 \mathrm{C} \% 22 \% 23 \mathrm{AAAAAA} \% 22 \% 2 \mathrm{C} \% 22 \% 23000000 \% 22 \% 2 \mathrm{C} 0.4 \% 5 \mathrm{D} \% 2 \mathrm{C} \% 5}$ B7500\%2C $27.850123 \% 2 \mathrm{C}-$

$82.173469 \% 2 \mathrm{C} \% 22 \% 23 \mathrm{AAAAAA} \% 22 \% 2 \mathrm{C} \% 22 \% 23000000 \% 22 \% 2 \mathrm{C} 0.4 \% 5 \mathrm{D} \% 2 \mathrm{C} \% 5 \mathrm{~B}$ 7500\%2C27.918688\%2C-

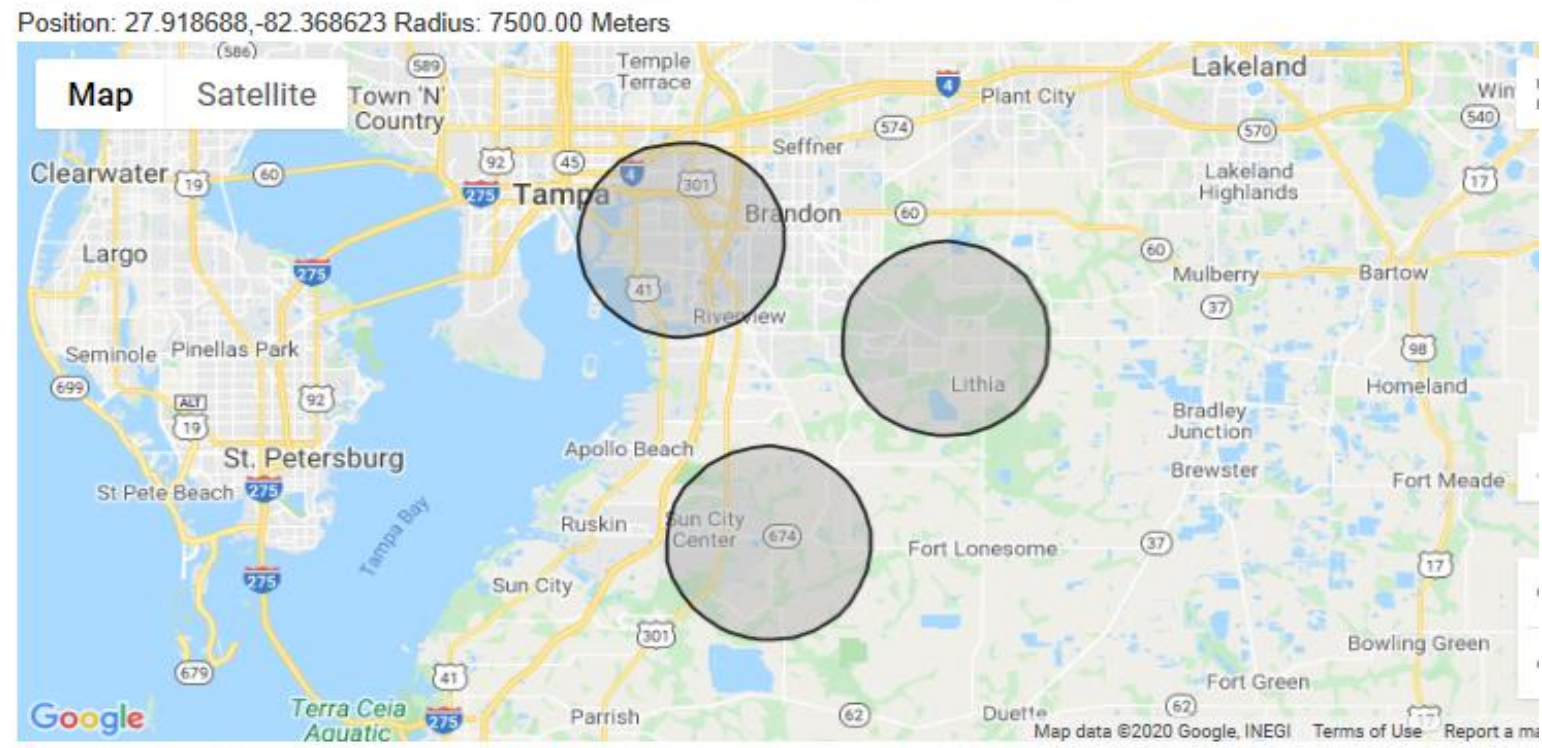

82.368623\%2C\%22\%23AAAAAA $\% 22 \% 2 \mathrm{C} \% 22 \% 23000000 \% 22 \% 2 \mathrm{C} 0.4 \% 5 \mathrm{D} \% 5 \mathrm{D}$

(Collins Map Developers Brick Buildings)

3. Wood Buildings: https://www.mapdevelopers.com/draw-circletool.php?circles $=\% 5 \mathrm{~B} \% 5 \mathrm{~B} 15000 \% 2 \mathrm{C} 27.7080057 \% 2 \mathrm{C}$ -

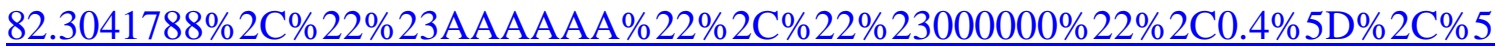

Position: 27.918688,-82.368623 Radius: 15000.00 Meters

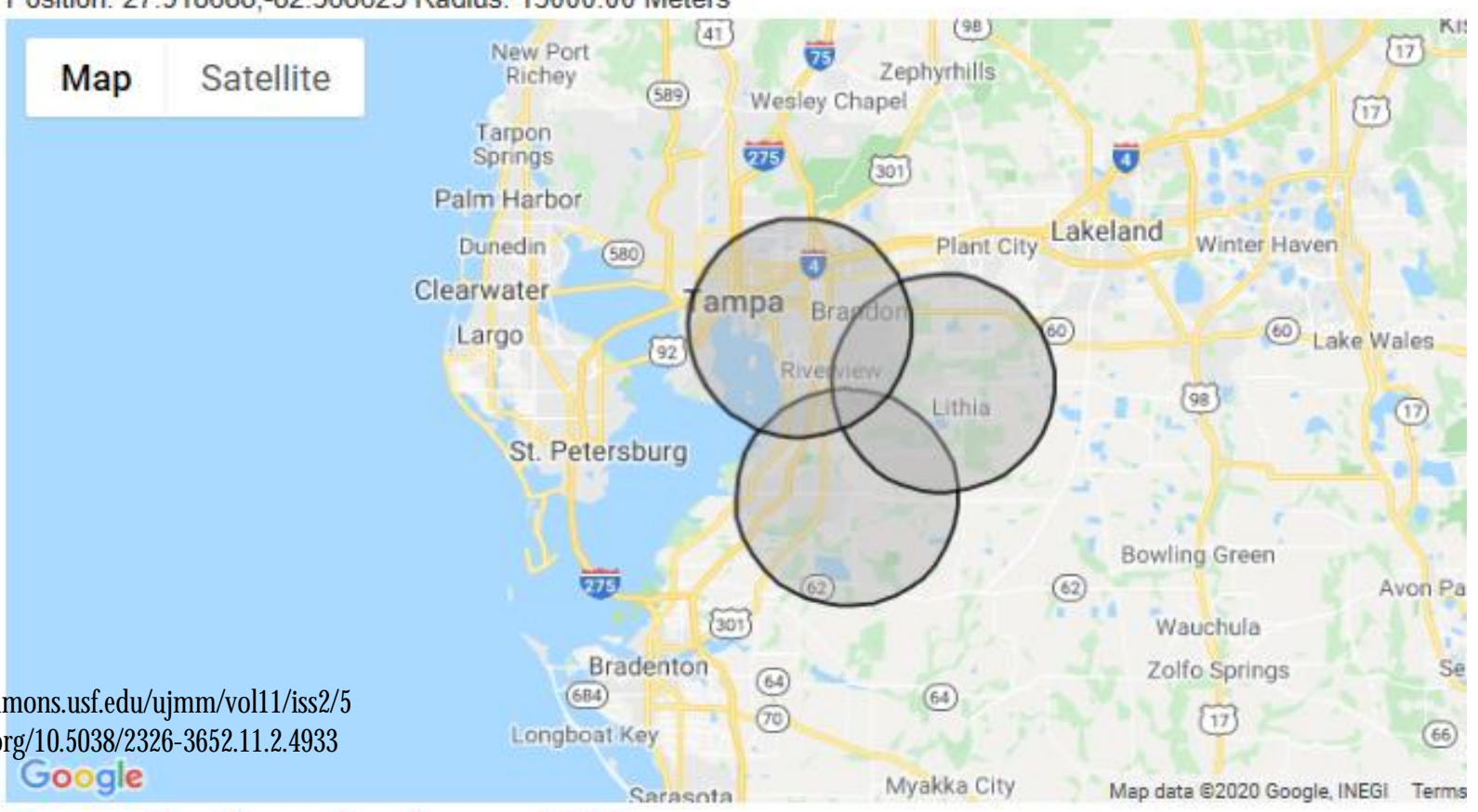

https://digitalcommons.usf.edu/ujmm/vol11/iss2/5 DOl: https://doi.org/10.5038/2326-3652.11.2.4933 
B15000\%2C27.850123\%2C-

82.173469\%2C $\% 22 \% 23 \mathrm{AAAAAA} \% 22 \% 2 \mathrm{C} \% 22 \% 23000000 \% 22 \% 2 \mathrm{C} 0.4 \% 5 \mathrm{D} \% 2 \mathrm{C} \% 5 \mathrm{~B}$ $15000 \% 2 \mathrm{C} 27.918688 \% 2 \mathrm{C}-$

82.368623\%2C\%22\%23AAAAAA $\% 22 \% 2 \mathrm{C} \% 22 \% 23000000 \% 22 \% 2 \mathrm{C} 0.4 \% 5 \mathrm{D} \% 5 \mathrm{D}$

\section{(Collins Map developers Wood Buildings)}

Radio waves have obvious distinction in their capability to travel through different building materials. Each map illustrates this distinction with wood structures having the greatest radio wave transparency, whereas, brick and concrete buildings are more stifling. This project has allowed me to explore emergency communication coverages in our local area. My project has several implications for engineering, with respect to radio communications and life safety. Accurately predicting emergency communication coverages at a location could revolutionize the Bi-Directional Amplifier industry as it significantly reduces time and resources spent on site surveys. Moreover, it is helpful for engineers in dealing with BDA systems when listing specifications for their new construction projects.

\section{Conclusions \& Recommendations}

The Bi-Directional Amplifier (BDA) is the newest edition to Life Safety in the state of Florida. The Florida Fire Prevention Code (NFPA 1) section 11.10.1 states that "In all new and existing buildings, minimum radio signal strength for fire department communications shall be maintained at a level determined by the authority having jurisdiction. Unfortunately, several building owners are unaware of the updated fire prevention codes and therefore, risk closure of their businesses. The largest issue for the Life Safety Industry today, is being able to decisively determine which buildings are not within code at an efficient rate. The goal of this project was to investigate different strategies to enhance emergency radio communications. The first formula I analyzed was the power in watts to decibel conversion. I chose this formula to start my project because if we could boost the decibel coverage from its origin of transmission then we would arrive at an overall solution with more ease. Unfortunately, through deriving the first and second derivatives of the power to decibel conversion, I came to the conclusion that as you add more power to the formula you receive less decibel gain per watt and therefore an impractical strategy for my problem statement. The next strategy I decided to investigate was finding a way to produce radio frequency coverage maps that are adequate per the Florida Fire Prevention Code. This led me to derive a formula for Free Space Path Loss in decibels using megahertz and kilometer units. With the FSPL formula I was able to graph a set of distances and their produced decibel losses. Next, I analyzed the FSPL graph by taking its derivative to see how distance affected decibel loss per kilometer. Lastly, I added building material loss constants to hone in on accurate results and to provide a variety of coverage maps. Using the formula of the area of a circle I was able to produce emergency radio communication coverage maps in kilometers squared. If someone would like to approach the same project, I would suggest looking in to providing coverage maps of different areas across the United States. It is only a matter of time before other states adopt these Life Safety regulations and with new locations will come new sets of variables for the formulas. For example, transmitter power levels, building materials, and emergency frequencies could all be different and these need to be taken account for. For new 
project ideas, I would suggest deriving a formula for variables that account for inside wall building materials as well as surrounding obstructions that cause radio wave diffraction. These may prove to be difficult, but with the right calculus tools employed, solutions are inevitable.

\section{Nomenclature}

\begin{tabular}{|c|c|}
\hline$g(x)$ & Watts to $\mathrm{dB}$ conversion \\
\hline$g^{\prime}(x)$ & $\mathrm{dB} /$ watts \\
\hline$g^{\prime \prime}(x)$ & $\mathrm{dB} /(\text { watts })^{2}$ \\
\hline$f(x)$ & Free Space Path Loss (FSPL) in $\mathrm{dB}$ \\
\hline$f^{\prime}(x)$ & $\mathrm{FSPL}(\mathrm{dB}) / \mathrm{km}$ \\
\hline$f^{\prime \prime}(x)$ & $\mathrm{FSPL}(\mathrm{dB}) /(\mathrm{km})^{2}$ \\
\hline$C$ & Concrete building constant \\
\hline$B$ & Brick building constant \\
\hline$W$ & Wood building constant \\
\hline W & Watts \\
\hline $\mathrm{Km}$ & Kilometers \\
\hline $\mathrm{dB}$ & Decibels (short for $\mathrm{dBm}$ ) \\
\hline $\mathrm{dBm}$ & Decibel milliwatt \\
\hline$\lambda$ & Wavelength \\
\hline $\mathrm{c}$ & Speed of Light constant \\
\hline$v$ & Frequency \\
\hline FSPL & Free Space Path Loss \\
\hline $\mathrm{r}$ & Radius \\
\hline$\pi(r)^{2}$ & Area of a circle \\
\hline FCC Callsign & Unique government designated tower \\
\hline$x$ & Input variable \\
\hline$\frac{d y}{d x}$ and $\frac{d^{2} y}{d x^{2}}$ & Leibniz Notation \\
\hline
\end{tabular}




\section{REFERENCES}

B., Nicky. “Technical \& Sales Resources for RSI Distributors.” Radio Solutions Inc., Radio Solutions Inc., rsibda.com/news/minimum-inbound-outbound-signal-strength/.

Collins, Austin. Map Developers, 25 Apr. 2020, www.mapdevelopers.com/draw-circletool.php?circles $=\% 5 \mathrm{~B} \% 5 \mathrm{~B} 15000 \% 2 \mathrm{C} 27.7080057 \% 2 \mathrm{C}-$ $82.3041788 \% 2 \mathrm{C} \% 22 \% 23 \mathrm{AAAAAA} \% 22 \% 2 \mathrm{C} \% 22 \% 23000000 \% 22 \% 2 \mathrm{C} 0.4 \% 5 \mathrm{D} \% 2 \mathrm{C} \% 5 \mathrm{~B}$ $15000 \% 2 \mathrm{C} 27.850123 \% 2 \mathrm{C}-$ $82.173469 \% 2 \mathrm{C} \% 22 \% 23 \mathrm{AAAAAA} \% 22 \% 2 \mathrm{C} \% 22 \% 23000000 \% 22 \% 2 \mathrm{C} 0.4 \% 5 \mathrm{D} \% 2 \mathrm{C} \% 5 \mathrm{~B} 1$ $5000 \% 2 \mathrm{C} 27.918688 \% 2 \mathrm{C}-$

$82.368623 \% 2 \mathrm{C} \% 22 \% 23 \mathrm{AAAAAA} \% 22 \% 2 \mathrm{C} \% 22 \% 23000000 \% 22 \% 2 \mathrm{C} 0.4 \% 5 \mathrm{D} \% 5 \mathrm{D}$.

Collins, Austin. Map Developers, 25 Apr. 2020, www.mapdevelopers.com/draw-circletool.php?circles=\%5B $\% 5 \mathrm{~B} 5000 \% 2 \mathrm{C} 27.918688 \% 2 \mathrm{C}-$ $82.368623 \% 2 \mathrm{C} \% 22 \% 23 \mathrm{AAAAAA} \% 22 \% 2 \mathrm{C} \% 22 \% 23000000 \% 22 \% 2 \mathrm{C} 0.4 \% 5 \mathrm{D} \% 2 \mathrm{C} \% 5 \mathrm{~B} 5$ $000 \% 2 \mathrm{C} 27.850123 \% 2 \mathrm{C}-$

$82.173469 \% 2 \mathrm{C} \% 22 \% 23 \mathrm{AAAAAA} \% 22 \% 2 \mathrm{C} \% 22 \% 23000000 \% 22 \% 2 \mathrm{C} 0.4 \% 5 \mathrm{D} \% 2 \mathrm{C} \% 5 \mathrm{~B} 5$ $000 \% 2 \mathrm{C} 27.7080057 \% 2 \mathrm{C}-$

$82.3041788 \% 2 \mathrm{C} \% 22 \% 23 \mathrm{AAAAAA} \% 22 \% 2 \mathrm{C} \% 22 \% 23000000 \% 22 \% 2 \mathrm{C} 0.4 \% 5 \mathrm{D} \% 5 \mathrm{D}$.

Collins, Austin. Map Developers, 25 Apr. 2020, www.mapdevelopers.com/draw-circletool.php?circles $=\% 5 \mathrm{~B} \% 5 \mathrm{~B} 7500 \% 2 \mathrm{C} 27.7080057 \% 2 \mathrm{C}-$ $82.3041788 \% 2 \mathrm{C} \% 22 \% 23 \mathrm{AAAAAA} \% 22 \% 2 \mathrm{C} \% 22 \% 23000000 \% 22 \% 2 \mathrm{C} 0.4 \% 5 \mathrm{D} \% 2 \mathrm{C} \% 5 \mathrm{~B}$ $7500 \% 2 \mathrm{C} 27.850123 \% 2 \mathrm{C}-$

$82.173469 \% 2 \mathrm{C} \% 22 \% 23 \mathrm{AAAAAA} \% 22 \% 2 \mathrm{C} \% 22 \% 23000000 \% 22 \% 2 \mathrm{C} 0.4 \% 5 \mathrm{D} \% 2 \mathrm{C} \% 5 \mathrm{~B} 7$ $500 \% 2 \mathrm{C} 27.918688 \% 2 \mathrm{C}-$

$82.368623 \% 2 \mathrm{C} \% 22 \% 23 \mathrm{AAAAAA} \% 22 \% 2 \mathrm{C} \% 22 \% 23000000 \% 22 \% 2 \mathrm{C} 0.4 \% 5 \mathrm{D} \% 5 \mathrm{D}$.

"FCC Callsign WPDV262 (Hillsborough Co. Sheriff's Office)." WPDV262 (Hillsborough Co. Sheriff's Office) FCC Callsign Details, Radio Reference LLC, 30 Apr. 2020, 5:41 pm, www.radioreference.com/apps/db/?fccCallsign=WPDV262.

"FCC." ULS License - PubSafty/SpecEmer/PubSaftyNtlPlan,806-817/851-862MHz,Trunked License - WPDV262 - Hillsborough Co. Sheriff's Office - Frequencies Summary, wireless2.fcc.gov/UlsApp/UlsSearch/licenseFreqSum.jsp?licKey=1301307\&keyLoc=1414 0574\&pageNumToReturn $=1$. 
"Hillsborough County (EDACS) - Site Map." Site Map: Hillsborough County (EDACS)

Trunking System, Hillsborough County, Florida, Radio Reference LLC, 4 Apr. 2020, 9:34 $\mathrm{am}, \mathrm{w} w \mathrm{w} \cdot \mathrm{radioreference} . \mathrm{com} / \mathrm{apps} / \mathrm{db} /$ action=siteMap\&sid=220\&type $=\mathrm{fcc}$.

"Hillsborough County (EDACS)." East System Site Details (Hillsborough County (EDACS)), Radio Reference LLC, 4 Apr. 2020, 9:34 am, www.radioreference.com/apps/db/?siteId=217.

Kayla. "Wavelength Equation." Calculations with Wavelength and Frequency, Chemguide.co.uk, 23 June 2016, socratic.org/questions/what-is-the-frequency-of-greenlight-with-a-wavelength-of-530-10-9-m.

Kuo, Yajun. "Derivation the DB Version of the Path Loss Equation for Free Space." Derivation the DB Version of the Path Loss Equation for Free Space., Www.ece.uvic.ca, 19 Sept. 2000, www.ece.uvic.ca/ peterd/35001/ass1a/node1.html.

United States, Congress, Committee, Technical. "NFPA 1: Fire Code 2018." NFPA 1: Fire Code 2018, vol. 1, National Fire Protection Association, 2017. Sec. 11.10.1-11.10.2.

United States, Congress, Senate, Florida. "Florida Legislature." Florida Legislature, Florida Senate, 2018. Statute 633.202.

\section{$\underline{\text { APPENDICES }}$}

Code Reference

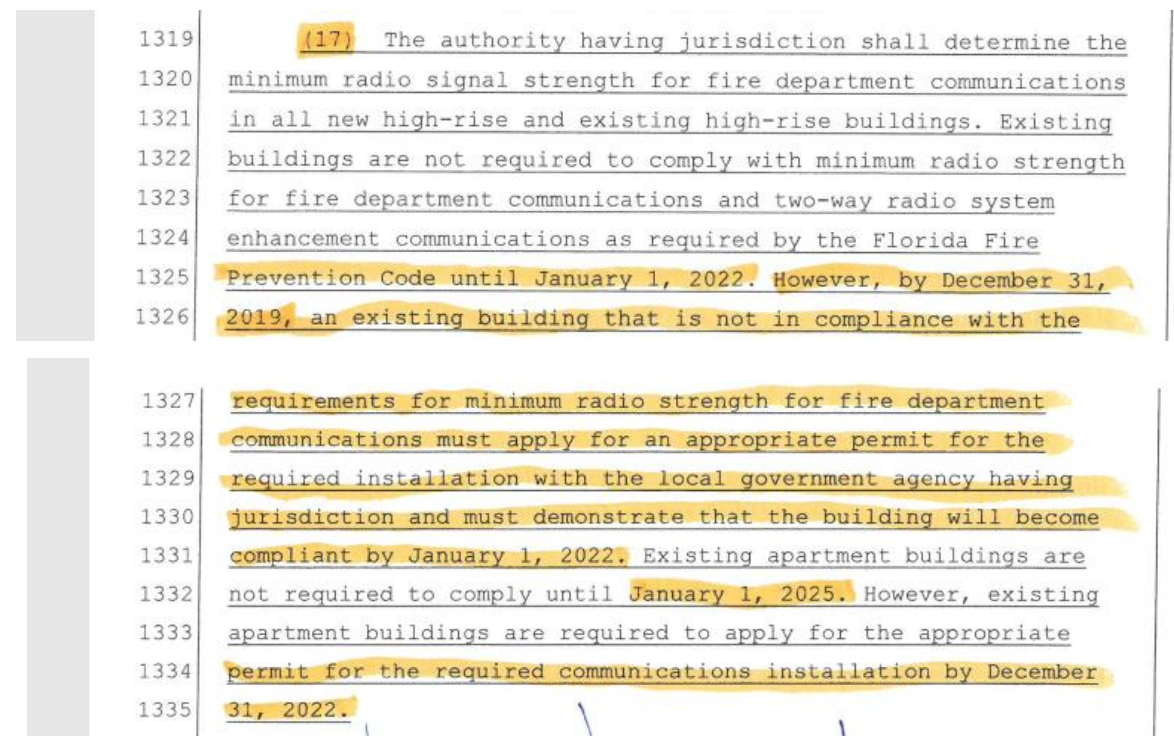




\section{Code Reference}

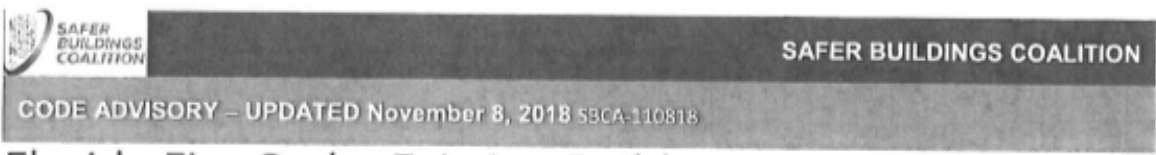

\section{Florida Fire Code: Existing Buildings Timetable}

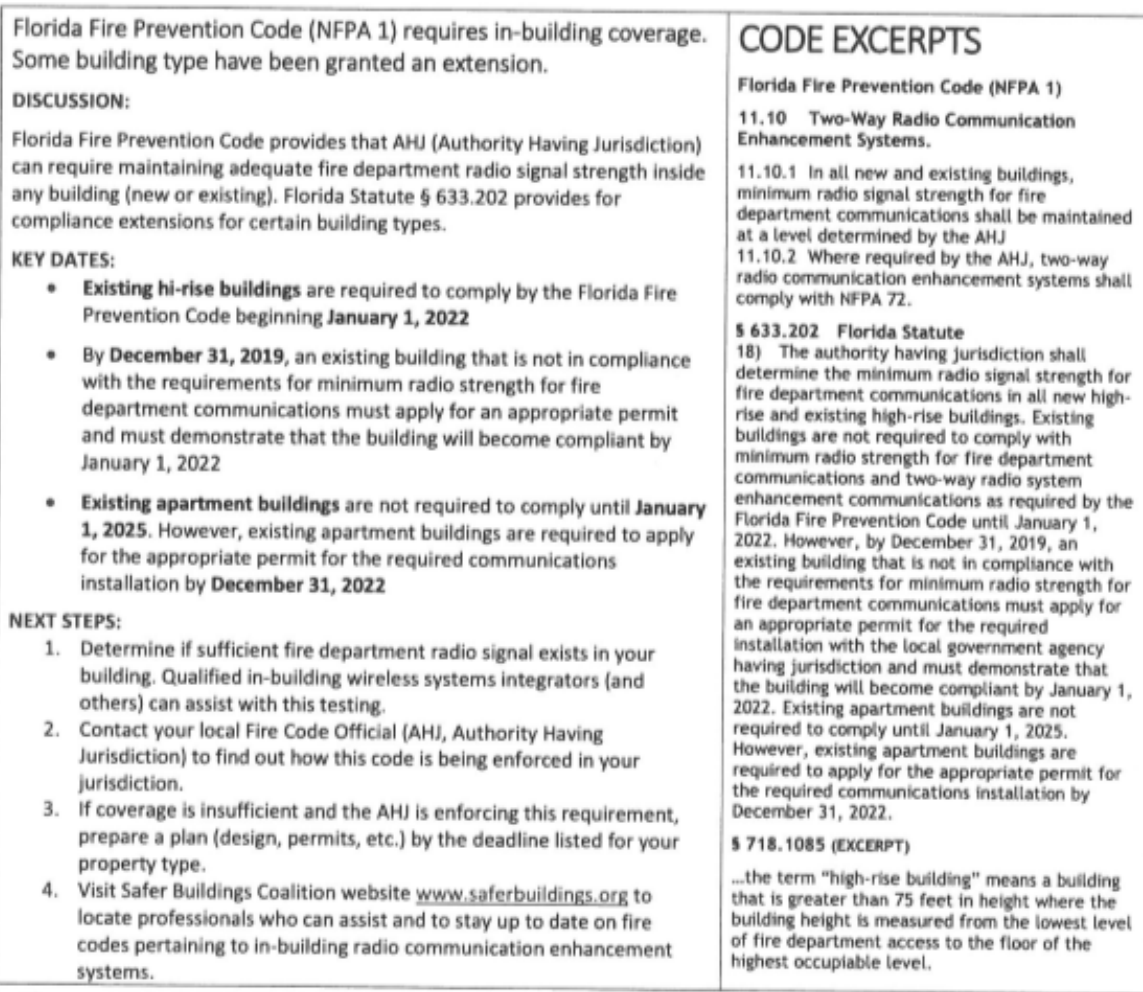


Site Survey Example 1

\begin{tabular}{|c|c|c|c|c|c|c|c|c|}
\hline Point & $\begin{array}{l}\text { Hand } \\
\text { Held } \\
\text { Gain } \\
(\mathrm{dBm})\end{array}$ & $\begin{array}{l}\text { Donor } \\
\text { Tower } \\
\text { Gain } \\
(\mathrm{dBm})\end{array}$ & Frequency & $\begin{array}{l}\text { Inbound } \\
\text { Downlink } \\
\text { RSSI (dBm) }\end{array}$ & PASS/FAIL & $\begin{array}{l}\text { Path } \\
\text { Loss }\end{array}$ & $\begin{array}{l}\text { Outbound } \\
\text { Uplink } \\
\text { RSSI(dBm) }\end{array}$ & PASS/FAIL \\
\hline $\begin{array}{l}\text { OUTSIDE SE } \\
\text { Corner }\end{array}$ & 34 & 51.76 & 02851.700 & -75 & PASS & 126.76 & -92.76 & PASS \\
\hline $\begin{array}{l}\text { OUTSIDE NE } \\
\text { Corner }\end{array}$ & 34 & 51.76 & 02851.700 & -70 & PASS & 121.76 & -87.76 & PASS \\
\hline $\begin{array}{l}\text { OUTSIDE SW } \\
\text { Corner }\end{array}$ & 34 & 51.76 & 02851.700 & -76 & PASS & 127.76 & -93.76 & PASS \\
\hline $\begin{array}{l}\text { OUTSIDE NW } \\
\text { Corner }\end{array}$ & 34 & 51.76 & 02851.700 & -85 & PASS & 136.76 & -102.76 & FAIL \\
\hline Fire Pump Room & 34 & 51.76 & 02851.700 & -100 & FAIL & 151.76 & -117.76 & FAIL \\
\hline Sprinkler Riser 1 & 34 & 51.76 & 02851.700 & -85 & PASS & 136.76 & -102.76 & FAIL \\
\hline Sprinkler Riser 2 & 34 & 51.76 & 02851.700 & -85 & PASS & 136.76 & -102.76 & FAIL \\
\hline $\begin{array}{l}\text { Electric Room / } \\
\text { FACP }\end{array}$ & 34 & 51.76 & 02851.700 & -95 & PASS & 146.76 & -112.76 & FAIL \\
\hline ROOF SE Corner & 34 & 51.76 & 02851.700 & -67 & PASS & 118.76 & -84.76 & PASS \\
\hline ROOF NE Corner & 34 & 51.76 & 02851.700 & -60 & PASS & 111.76 & -77.76 & PASS \\
\hline ROOF SW Corner & 34 & 51.76 & 02851.700 & -64 & PASS & 115.76 & -81.76 & PASS \\
\hline ROOF NW Corner & 34 & 51.76 & 02851.700 & -64 & PASS & 115.76 & -81.76 & PASS \\
\hline
\end{tabular}

Site Survey Example 2

\begin{tabular}{|c|c|c|c|c|c|c|c|c|}
\cline { 6 - 9 } 10 & $3 / 12 / 2020$ & 34 & 51.76 & $-\mathbf{7 8}$ & PASS & 129.76 & $\mathbf{- 9 5 . 7 6}$ & FAIL \\
\hline 11 & $3 / 12 / 2020$ & 34 & 51.76 & $\mathbf{- 7 5}$ & PASS & 126.76 & $\mathbf{- 9 2 . 7 6}$ & PASS \\
\hline 12 & $3 / 12 / 2020$ & 34 & 51.76 & $\mathbf{- 7 9}$ & PASS & 130.76 & $\mathbf{- 9 6 . 7 6}$ & FAIL \\
\hline 13 & $3 / 12 / 2020$ & 34 & 51.76 & $\mathbf{- 7 4}$ & PASS & 125.76 & $\mathbf{- 9 1 . 7 6}$ & PASS \\
\hline 14 & $3 / 12 / 2020$ & 34 & 51.76 & $\mathbf{- 8 0}$ & PASS & 131.76 & $\mathbf{- 9 7 . 7 6}$ & FAIL \\
\hline 15 & $3 / 12 / 2020$ & 34 & 51.76 & $\mathbf{- 7 0}$ & PASS & 121.76 & $\mathbf{- 8 7 . 7 6}$ & PASS \\
\hline 16 & $3 / 12 / 2020$ & 34 & 51.76 & $\mathbf{- 7 8 . 5}$ & PASS & 130.26 & $\mathbf{- 9 6 . 2 6}$ & FAIL \\
\hline 17 & $3 / 12 / 2020$ & 34 & 51.76 & $\mathbf{- 7 5}$ & PASS & 126.76 & $\mathbf{- 9 2 . 7 6}$ & PASS \\
\hline 18 & $3 / 12 / 2020$ & 34 & 51.76 & $\mathbf{- 7 8 . 5}$ & PASS & 130.26 & $\mathbf{- 9 6 . 2 6}$ & FAIL \\
\hline 19 & $3 / 12 / 2020$ & 34 & 51.76 & $\mathbf{- 7 4 . 5}$ & PASS & 126.26 & $\mathbf{- 9 2 . 2 6}$ & PASS \\
\hline
\end{tabular}

